\title{
InfoNorth
}

\section{Arctic Patrol Beyond Niflheim: Traveling the Far Northern World of the Dead}

\author{
By Torben Eriksen
}

$\mathbf{S}$ ince WWiI, Denmark has patrolled the uninhabited parts of Greenland to maintain Danish sovereignty over the uninhabited area. The patrol, named the Sirius Patrol, is part of an elite unit of the Danish Special Forces. Two-man teams, consisting of $12 \mathrm{men}$, six newcomers and six one-year members, each of whom are obliged to at least 26 months of service without scheduled time off, crisscross East and North Greenland by dogsled (Fig. 1). Sirius is based in Daneborg, East Greenland, nearly $300 \mathrm{~km}$ from the nearest neighbor; they receive one annual supply ship.

I spent my youth as a member of the Sirius Patrol $(1965-73)$ and have put to paper some of the more memorable experiences and events that took place during my years on patrol. All events are told exactly as I remember them; but for the sake of brevity and to make the story more interesting, I have woven the events together as a single, long trip.

Each Sirius team was assigned to patrol two areas over the winter. The fall tours started in early November after the sun had vanished for the year, and each day only got darker. The teams stumbled around for 4-6 weeks, trying to find their way and return before Christmas. It was a miserable experience that only a Lutheran could enjoy. The spring tours normally started in early February as the sun was returning and lasted 4-5 months.

I never got used to the difference between a warm building and the intense cold outside. The snow squeaked under my boots, ice formed in my nose hair, the cold air burned my lungs, and I often feared not being able to tolerate it. As soon as the $70-80$ dogs saw a sled being loaded, they created bedlam. They yanked their chains, jumped around, and howled, but still had time to claim ownership of any new patrol member by peeing on his legs. After many years of careful breeding, the dogs loved to pull, eat, and fight - a fringe benefit (Fig. 2). The other patrol members helped harness and hitch their 12 frantic animals to the sleds. The dogs had been resting for some weeks and wanted action. Often the departures were chaotic, the dogs fought, changed course, ran between buildings, got entangled, attacked other dogs, or crashed down steep slopes to bystanders' great amusement. In the past, the Church of Denmark pre-emptively absolved

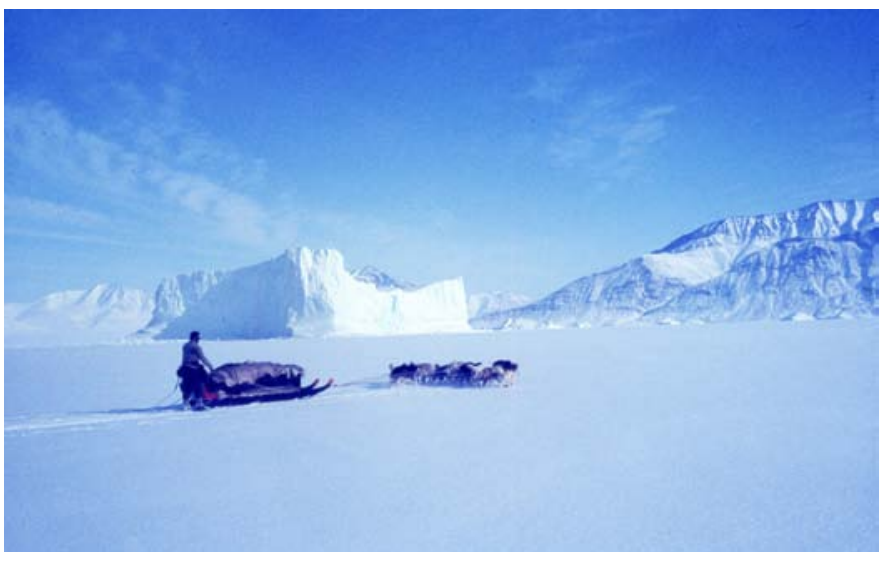

Fig. 1. Sirius Patrol sled traveling a Greenlandic fjord.

missionaries who visited Inuit settlements by dogsled for yelling and swearing at their dogs.

My team made it back from the fall trek just in time to prepare for the spring trip. Our assignment was to patrol designated areas of East and North Greenland that weren't covered by the inland ice. Robeson Channel, bordering Canada, was to be our turn-around point. To make it to the airstrip for transportation to North Greenland on time, we had to leave in mid-January. If everything went well, we would return before the sea ice broke up in late June.

As usual, the team ran flat out when they started, this time departing the station without incident. Inevitably, the dogs immediately pooped and peed. Doing that in full gallop is a skill nobody should master. The fresh urine and excrement froze to our skis and sled runners, and we busied ourselves steering around it. Until the dogs had been on the go for some weeks, each start was a barely controlled chaos, as our sleds had no brakes. It was hard exercise and if it was cold enough, ice formed in our beards and froze our mouths open, adding to the comedic scene.

It was dark 24 hours a day, the sun still three weeks from reappearing, but at least we were travelling south towards a brighter horizon. In the dark, snow-covered obstacles on a white landscape were hard to see, and as we almost always skied to stay warm and ease the dogs' load, we fell a lot. For that reason, a long rope dragged behind the sled. If we both fell, we would grab the rope and hold on regardless of 


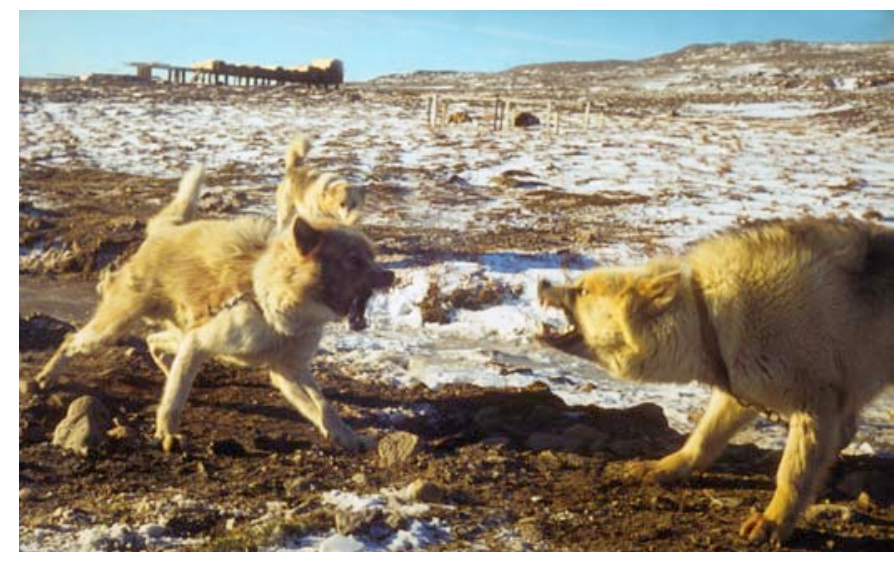

Fig. 2. Dispute between two members of the dog team.

the terrain, otherwise the dogs would take off-sometimes going on by themselves for days. Navigation was basic; we mainly followed the coast, occasionally verifying the direction with our compass. When it was pitch dark and clear weather, we could get an idea of the height and shape of nearby mountains by noticing how much sky they blocked out.

The "patrolman's remorse" set-in a couple of days after leaving the home base: "Am I crazy, what am I doing here?" But it didn't last long. In Denmark, all applicants were thoroughly briefed about the hardships we could expect, and we were told not to sign up if we had any misgivings. For most, the assignment turned out to be very rewarding, and we came to love the challenges it offered.

In mid-winter, camping was a chore. We placed the low patrol tent on a level patch of snow and the dogs were chained nearby. They barked if a bear approached. We had to keep careful track of the snow, not only for our safety, but for that of the dogs.' The limited precipitation in North and East Greenland could create a harmful situation for thirsty dogs. When the salt froze out of new ice and mixed with a fine layer of snow it created a briny mixture that wasn't safe for drinking. With a candle as illumination, we placed the food and primus stoves in the middle of our tent and our sleeping bags at each side. Our eyes stung and we coughed from the stove fumes. Some genius in Denmark had deemed that jet fuel was a suitable stove fuel! We could not stand up inside the tent; all activities were done sitting or lying down. As soon as the stoves were turned off, we crawled into our down bags, which were inside canvascovered reindeer skin mummy bags. We placed our rifles under the ground pad, which kept them cold and avoided condensation that would freeze the metal parts together.

After some nights of snow camping, signs indicated that a storm was brewing, so we decided to seek shelter in an abandoned hunting station. I searched for the building on land, while my partner remained on the ice, where travelling was easier. As usual, the flashlight was frozen and unusable. Even so, when patrolling in the dark, artificial light was of questionable benefit, as it instantly spoiled night vision, which was slow to redevelop. Even if only striking a match, we would warn our partners to look away. Eventually I ran into the roof of the station, which was sticking above the snow. I then had to find my partner and the dogs and relocate the building. The snow was very hard and left no tracks to follow, but finally we found each other and the building and excavated a door. The door led to a storage room, not the living quarters. After some serious tunneling we found the proper entry, took care of the dogs and moved in. With snow around the outer walls, we easily heated the building with the coal-fired stove. The twoday storm gave us plenty of time to worry about carbon monoxide poisoning.

Farther down the coast and sometime later, we again decided to spend the night in an abandoned hunting station. Again, I searched on land while my partner stayed on the ice. As I stumbled around in the dark, I heard something walking in the snow; it had to be a bear. If a bear wasn't hibernating by mid-winter, they were hungry and would kill and eat a person, just like any other prey. A white bear on snow had the advantage in the dark. I had only my mandatory side arm for defense (my rifle was on the sled), so I decided to keep walking toward the cabin, determined not to show fear. Luckily, the cabin door was snow free and I quickly got in, lit a kerosene lamp, and warned my partner out on the ice, who made it to the cabin with the dogs without being attacked. Later, we found the paw prints; it turned out to be a small bear that had taken off.

In East Greenland there was a big difference between high and low tide. In winter, a narrow band of coastal ice rested on land, while the floating ice moved up and down with the ebb and flow. The break between the moving and stationary ice created either a hard-to-cross wall or a sheer drop-off, depending on the tide level. The eerie sound of large ice sheets rubbing against each other with the tide current mimicked the sound of a fast-moving animal running up to devour us in the night.

The next day, it was time for the team to depart the rough ice conditions of the outer coast and move to the fjords (Fig. 3). Travelling was easier there, not only for the stunning beauty, but because the fjords were mostly without the pack ice that hampered progress farther out. Occasionally we would pass icebergs that had broken apart, lost their equilibrium and rotated, unhindered by the 10-20-foot thick fjord ice frozen to them. As they broke apart and rotated, large chunks were flung away and would slide on top of the surrounding ice under the snow, creating what looked like oversized mole runs. Camp sites had to be chosen to avoid the risk to men of being injured by shifting ice.

I learned a lot about ice during my time on patrol, and we reported icebergs when we could. In some places, the inland ice in Greenland could reach a thickness of more than $3000 \mathrm{~m}$. Over the centuries, snow built up and compressed into ice as more weight built up on top. Driven by its mass, the ice slowly slid downhill to the coast, where large overhanging portions either separated from the glacier and fell into the sea or slid directly into the water, where it 


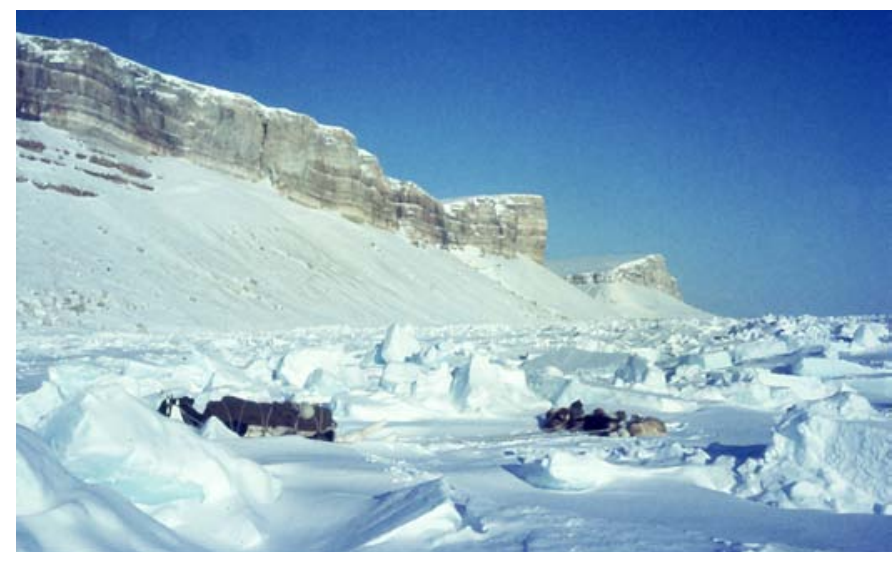

Fig. 3. Rough ice conditions at the outer coast.

became buoyant, was lifted by the water, and broke loose. An active glacier calved year-round. The bigger pieces of calved ice became icebergs, which were mainly huge pieces of milky, solid ice, but with weaker parts that got sculpted by the current and weather. A few bergs had already been tunneled through by melt water when they were part of the glacier, and the floating formations slowly became objects of incredible beauty.

Another kind of ice known as shelf ice started as floating ice attached to land. Like glacial ice, the snow on top of shelf ice didn't melt in summer and accumulated over the years. It too could reach a great thickness and large sections might separate and drift away as icebergs. Shelf ice was recognizable by its flat top.

We especially kept an eye out for growlers, which were slabs of floating ice that could be hazardous to shipping. Some were glass-clear, dense, and hard to see or detect on radar because they floated very low in the water. Growlers also formed in the inland ice, where pockets of meltwater, ponds, and lakes were common in the summertime. These froze solid in winter and would slide along with the rest of the ice. Pockets of trapped air under very high pressure would form when the water expanded as it froze. If we melted this type of ice for drinking water, it would explode in the pot. I often wondered if the high pressure in some bergs aided in their disintegration as they broke apart.

This was nature in the raw, incredible forces were released, and we were wise to stay clear of the ice. Other dangers were present near the shore as well. The large waves from the calving bergs created open water in front of glaciers. Seals took advantage of those, as they didn't need to make breathing holes, but their presence attracted polar bears. Some fjords were so narrow that the speed of the tidewater there kept the narrows from freezing over. In the dark it was risky to stumble around near open water, so we travelled on land as much as possible.

Most of the abandoned cabins and stations in East Greenland were built by hunters and trappers who eked out their living in the past. As we travelled through the fjords in the dark, we saw a dim black dot on shore, which we thought might be one of these huts. At the end of a long, hard day, the dogs were worn out; they had learned that the word "cabin" meant food and rest, so they made a last effort toward the black dot. We swung up to the building, set the dogs in chain, and dug down to the door. It was too dark to notice that apart from the front wall, the building had collapsed. At some point a bear had broken in, panicked and crashed out through another wall, leaving the ruined mess behind. What food the bear didn't eat, the Arctic foxes had claimed by urinating on it. Regardless of how hungry a sled dog is, it will not eat anything smelling of fox pee. So, we unchained the team and camped farther south.

We used surplus metal ammunition boxes for food storage when they were available. The bears couldn't open them and would sometimes in their frustration drag them away or pound on them so hard, the contents would be scattered all over. A bear did attack a dog one evening as we rested in a cabin. The dogs' barking and the screams from the attacked dog sent us outside, rifles in hand. As usual, we couldn't see a thing, but fired many rounds in the direction of the screams and killed both the bear and the dog, who had already had its stomach torn open. Only bears could make the patrol huskies bark, normally they howled. We skinned the attacker by lamplight, but wished it had left us alone. The bear was emaciated, with hardly any blubber under its skin, and its tracks revealed that it had followed us over a long distance.

At the bottom of the Loch Fyne fjord, the terrain that connects it to the neighboring fjord was low and featureless, and it was difficult to determine how much progress we had made. Eventually we got tired of guessing; we dug down through the snow and hit ice-we were on the fjord, or was it a lake? The question was settled by tasting the ice; it was fresh water, so we knew we still had some distance to go. I had read a lot about navigation, but that particular method had never been mentioned.

Deep loose snow was uncommon and detested by the entire patrol, who called it Christmas snow (Fig. 4). The sled, heavy and low with narrow runners, sunk in deep and was as difficult and cumbersome to haul through the snow as a heavy stepladder. Normally the dogs would walk next to each other, pulling the sled on individual ropes, but in Christmas snow, they had to pull two by two in a long line, so the front dogs compacted the snow and the rest could pull. One man on skis would lead the dogs to cheer them up, and if the snow was so deep that the dogs could swim in it, he had to walk sideways on the skis, taking very small steps to pack it down. After a long and hard day, when we could still see where we had camped the night before, even the dogs realized the futility of our efforts. If we waited it out in the tent for a couple of days, the snow would either solidify under its own weight, or get compacted by the wind. Being stuck in a tent was boring and against the nature of the patrol members who were aware that to conserve food and fuel they had to spend most of the time trying to sleep, supply drinking water by melting snow over a candle, and entertaining themselves by reading if the temperature allowed. Due to weight constraints, I had only brought two 


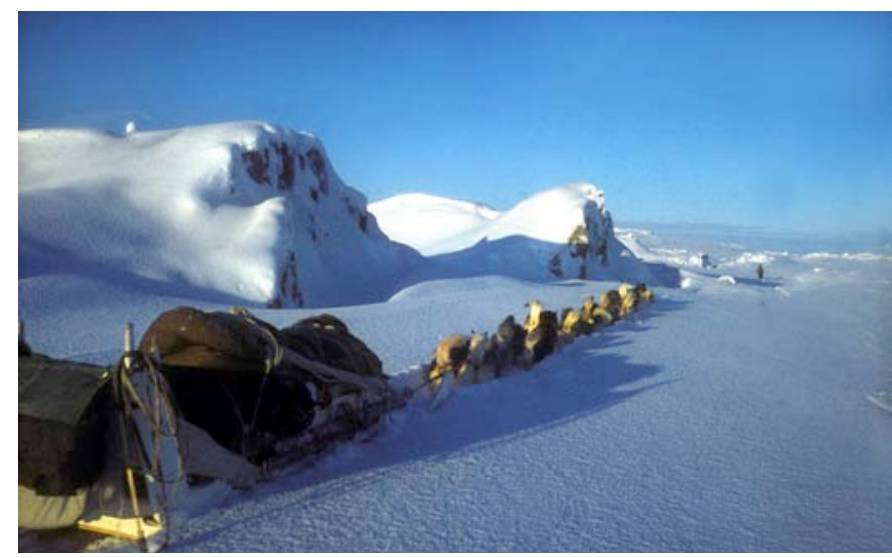

Fig. 4. Dogs being led through Christmas snow.

books on this trip, David Copperfield and The Saga of Gosta Berling, both of which I by now knew rather well.

Assessing the dog team's mood was fairly easy. After the dogs were chained, fed, and rested, all we had to do was mingle with them and imitate wolf howls. When happy, the dogs would sit up, lean their heads back, and bellow out some bone chilling wails (Fig. 5). These calls cemented the team, claimed the territory, and challenged other animals to answer. But on a cold Arctic night waiting out Christmas snow, no sound better expressed the dogs' hardship and loneliness; it was only underscored by the absence of an answer, regardless of how often the team called.

A maximum of two weeks travel between depots was a reasonable rule of thumb, as a longer distance would increase the amount of fuel, food, and dogs' rations we needed, which further slowed the team and created a cyclical need for additional provisions.

After a time, a brighter southern sky, now with the sun closer to the horizon, made travelling easier. One day we saw signs that a polar bear had rolled around in the snow with serious diarrhea, excreting foil paper all over. That didn't bode well for our next refueling stop, the patrol's largest remote depot. A bear had broken into the storage room and gone on a rampage, tearing into everything including soap powder, flour, coco powder, canned food, lemonade powder, jam, honey, you name it. Most had been torn open, rejected, and dropped on the floor, but the bear had eaten large amounts of canned food and chocolate, hence the foil paper. With its powerful jaws, a bear could flatten a can of frozen food and squeeze the contents out; however, they didn't know how to handle glass jars. Like the rampaged cabin we'd come across earlier, foxes had peed on everything in the depot. Instead of spending a couple of leisurely days at the station with a generator, we cleaned and repaired the building and prepared to head towards Mestersvig, a manned weather station a couple of day's travel farther south. The crew there sent weather observations every three hours, kept an airstrip open yearround, and assisted visitors who came in the summer.

As we departed the station and headed away from land, we saw a large triangular black object sticking out of the

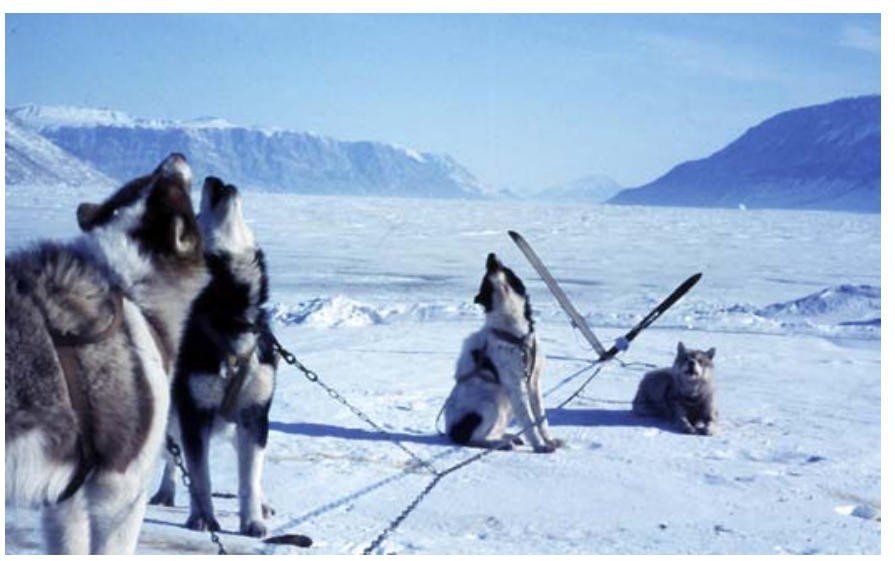

Fig. 5. Happy dogs at camp.

ice. My partner went to investigate and reported it was the head of a shark staring at him. "I am glad it wasn't anything unusual," I answered, my nature rather laconic, "Let's keep going." What we didn't know was that another team had hooked the fish earlier the same winter and that it was so big, they couldn't land it and had left it half out of the ice, held up by its fins. It was a Greenland shark, a deep-water scavenger belonging to the family of sleeper sharks. They are very slow moving, can live for hundreds of years, and could get very large. When it was brought to the surface, the rapid pressure change killed it. The Greenland shark's meat is loaded with ureic acid and is poisonous. Supposedly, the Inuit in Greenland could get a high from eating small amounts of it, but it also made them sick.

When we arrived in Mestervig, we found the station leader waiting for us away from the buildings and demanding police protection. He feared for his life; the staff wanted to kill him. He was so scared, he could barely light a cigarette. What he knew about management, he had learned picking apples in Tasmania.

In the evening we went for dinner in the cafeteria. The leader was seated at the end of the table, we flanked him, and the rest of the station crew sat farther down, all with their backs turned. The station leader pretended everything was normal, but for the longest time, nobody said a word. To break the silence, he eventually asked the crew how much ammunition he should order for the coming season. He was answered with deep silence until somebody said, "One bullet is enough." We had difficulty not cracking up with laughter.

Later the same evening the staff celebrated our arrival and got pretty drunk. The station leader managed to convince a problem employee to submit his resignation. The next day, after the worker had sobered up, he went to the chief's office, pounded on his desk until it started crumbling and was reinstated.

The cook at the station had been hired on for two years, planning to save enough money to start a French restaurant in Copenhagen. To keep up his skills, he cooked French food, which the crew hated. On the cook's days off, the handyman prepared plenty of meat, potatoes, and 
gravy, something the employees appreciated. One day the handyman decided to prepare a large roast; he retrieved the meat from the freezer and followed the cookbook to the letter. When the roast was placed on the table and the first person cut into it, a long silence followed before he said, "The permafrost is close to the surface this year, please hand me the gravy and potatoes." The handyman examined the roast: "That flunking cookbook never mentioned I had to unthaw the meat first!"

The morale at the station was so low that despite the hot showers and heated rooms, we couldn't wait for the transport plane - our ticket out - to arrive. The Danish Air Force was slated to fly us, the dogs, the sled, and our gear almost $1000 \mathrm{~km}$ farther north, but they kept having engine problems due to the low temperatures. Eventually, a plane arrived on February 28, a couple of weeks behind schedule, and on the first day that the sun briefly made an appearance above the horizon. The delay didn't leave much time to dally, and we started our journey the next morning, heading north and west.

At only $700 \mathrm{~km}$ from the North Pole, the sky was clear, but with a slight headwind and the temperature hovering between $-40^{\circ} \mathrm{C}$ and $-50^{\circ} \mathrm{C}$, travelling was a challenge. Our beards froze to the hoods of our parkas, the parkas to our woolen sweaters, and the sweaters froze to our shirts and our outer layers of underwear. After the tent was set up, it took a long time to unthaw and dry our clothes in a net above the primus stoves. We never extinguished them before our clothes, boots, and socks were dry, it would have been reckless. I was convinced rheumatism would be a problem later in life, as only the side of my body facing the stoves got warm. The barren landscape and extreme low temperatures in North Greenland offered few natural means for survival. Bad planning or equipment failure could have deadly consequences.

After resupplying at a depot that had been laid out by a sea plane in a large fjord the summer before, we continued toward the North Pass. Another storm was brewing; lensshaped clouds formed right above the mountains, and a stiff headwind picked up. As we got closer to the pass, we started seeing clear signs that strong winds were common in the area. The snow was packed together in large, hard, drifts, the exposed fjord ice was polished by the wind, and the terrain was blown snow free.

My partner started getting frostbite on his cheeks and had to keep rubbing them. On a creek a short distance inland, we were forced to camp. The location was terrible, but the dogs could no longer get foothold on the frozen stream to pull the load against the headwind and over the exposed rocks, and they avoided clear, freshwater ice. They tried to run around it, thinking they would fall through. We set the sled up as a windbreak and anchor for the tent, brought the supplies inside, and strapped everything else down to keep it from blowing away. The dogs were staked out on their chain, which was strung between the sled and a rock.

Inside the tent it was obvious that we couldn't set it up completely, it would have been torn to shreds. Instead, we pulled the fabric tight over our gear, placed ourselves on each side of the ground pad, crept into our bags, and folded the excess tent material under us. Due to the extreme cold, we had two down mummy bags inside each reindeer skin sleeping bag, and we could get in with all our clothes on if necessary.

Sleeping inside three mummy bags wasn't for anyone with claustrophobia, as it was too cold to keep one's head out. When I turned around, the openings of the bags easily got misaligned and I had to patiently rotate my body to align them again, so I could get out. In the morning, the reindeer skin flap was always covered with hoar frost from our breathing. The tent's interior was as cold as the outside, making the transition from the warm sleeping bag an unpleasantly frigid shock.

The wind increased enough that we were pelted with small rocks. To avoid freezing to death, we kept moving in our bags, yelling to each other to stay awake. At times we could hear the dogs howling over the wind. They were miserable on the windblown ground with no snow to protect them.

Sometime that night I had to pee and reluctantly got out of the tent, trying not to make a mess. That turned out to be a bad idea. The wind blew me along the ground and I had to claw my way back on my belly. With only thin gloves on, my fingertips froze and the skin later peeled off. Riding out the storm, my mind slowly cleared; I became very peaceful and completely focused. Nature wasn't out to get us, these conditions had to be expected. We were the intruders and had taken all possible measures to survive; there was nothing more to be done and nobody to help us. If the weather got much worse, we would die. No regrets cluttered my mind; I didn't have flashbacks, didn't think about friends or family, but was fully centered on the present and experienced total clarity. Some have described this as finding peace with your maker. It was a strange experience, but somehow very comforting.

After a long night, the wind finally died down, and exhausted as we and the dogs were, we broke camp to get away from that miserable site. Less than $10 \mathrm{~km}$ farther inland the snow was deep and powdery; the storm had been local.

In Arctic storms, cloud cover keeps the energy that has reached the Earth trapped, but during this local storm the sky had remained clear, and we could only wonder how much heat had radiated back out and what the wind chill factor and temperature had been. We theorized that any difference in wind, temperature, or barometric pressure between the two large and deep fjord systems we were traveling in caused the strong storms in the pass. The wind would continue until the atmospheric conditions were the same on each side. Had we not been very well trained and equipped with the best gear available, we would have died in that storm, no doubt about it.

The hairless pads under some of the dog's paws had frozen and came off as we went along. We could see the exposed sinew below and attempted to protect their paws 
with spare socks. We had to cover a long distance before the thaw in late June or risk getting stuck at some cabin for the summer. With depots of limited size, we couldn't wait for the dogs' paws to heal. Several bled with each step and had to take turns resting on the sled, weakened as they were by blood loss.

With the limping dogs we went through the North Pass, De Long Bay, and onward along the north coast of Greenland heading west. We fed the dogs daily rations of about 5000 calories, roughly the same as ourselves, but the dogs slept in the open and were always hungry. They would scarf down anything within reach: gloves, rope, boots, anything. I was often puzzled why they didn't kill and eat us as well.

One day we saw a parachute on land, billowing in the wind, just as described in Lord of the Flies, but without the dead airman. Apart from the chute, there was nothing at the drop site, and all we could do was report the find. Another day, we came over the aluminum frame from a rather substantial tent and guessed that some outfit had made illegal preliminary oil and mineral explorations many summers ago in case the area was ever opened up for concessions.

The weather was very stable and now affected by the inland climate in Canada, which made it extremely cold. We often had a slight headwind and estimated (the alcohol thermometer had frozen) the temperature at around $-50^{\circ} \mathrm{C}$ to $-60^{\circ} \mathrm{C}$ in the daytime. On very cold nights, the fuel in the stoves jellified and had to be preheated with fuel tablets. The tent was single walled to allow the heat from the stoves to melt the ice on its outside, which would prevent the fabric from breaking during packing. If it wasn't too cold, the sled would glide on a thin film of water, created by the friction between the snow and the runners. But at very low temperatures, the snow would freeze to the metal instead, and pulling it was hard on the dogs. To alleviate the problem, we melted snow and mixed it with a solid-a little pure cocoa powder worked well-and rubbed it on the runners with a rag (Fig. 6). The frozen mixture was much stronger than ice alone, but we had to avoid driving over any sharp edge, which would scrape it off. With the mixture on the runners, we could push the sled with one hand and the protesting, squealing sound caused by the friction against the snow was gone. We built our own sleds according to certain minimum requirements but were free to add our own improvements. To make repairs in the field possible, the sleds were lashed together with braided nylon cord - nuts, bolts, and screws were not acceptable.

We ate only two meals a day in the tent because it was too cold to cook while traveling. Part of our breakfast was sweetened condensed milk and raw oatmeal, which came in cardboard boxes with cut-out figures and dresses for children to play with. For fun, we pretended to exchange cut-outs with the other teams over the radio. We could only wonder what outsiders who listened in on our conversations thought. After all, this was during the Cold War and somebody was paying attention, jamming our communications on occasion.

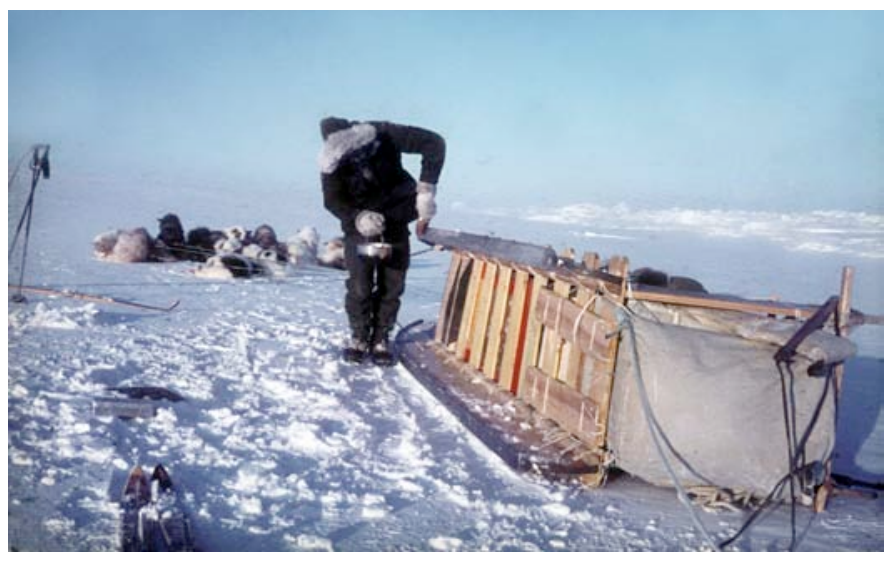

Fig. 6. Icing the runners on the handmade sleds.

When we had low temperatures and calm weather, the frozen radiated heat from the dog team made its own contrail. We could look back and see our direction of travel. The ice was unbroken and lifeless: there weren't any marine mammals and hence no bears; the land was absent of wolves, foxes, ravens, gulls, and even Inuit hunters. The silence was total and eerie. Had the area been populated, we wouldn't have been needed. Our sole purpose was to maintain Danish sovereignty over desolate territories in northern Greenland by traveling over them, reporting flyovers, looking for submarines, surface ships, and any other signs of illegal activity on land by foreign powers. That was how the patrol had started during WWII when the Germans established clandestine weather stations along the east coast of Greenland.

Seeing high flying passenger planes was bad for our morale. In the time it took the jet to travel from horizon to horizon, our sleds might have covered less than a staggering half kilometre. We knew the passengers were warm and comfortable, had food and drinks, and that the stewardesses were pretty. We, however, were a sight only a mother could love: smelly, covered with patches of hoar frost, and barely house broken. Once, a passenger plane did report a black dot and a track in the snow far below. They had radioed Mestersvig because they had no clue who or what it might be. They couldn't have known it was us.

The patrol didn't accept applicants who needed glasses as these as well as sunglasses iced over on cold days. To prevent snow blindness, we avoided staring too long at areas that reflected lots of sunlight, pack ice for example, and focused on the dogs instead.

Only huskies made it possible for Sirius to patrol northern Greenland with so little logistical support. For more than two month's travel so close to the North Pole, we needed good equipment, four depots, 12 highly motivated dogs, and nothing more. No mechanical conveyance could have handled that kind of terrain or been reliable at such low temperatures, nor would it have greeted us in the morning and begged to get moving.

The ice in the Arctic Basin rotated counterclockwise and got pushed high up on any land which stood in its 
way. At a few places, the current was so strong there was open water, and it didn't take much imagination to picture the consequences if we fell in. It made me remember the description of Nifleim in Norse mythology, as the far northern world of the dead, with icy fog and darkness, cold and mist, and ruled by the goddess Hel. And that about said it.

The visibility was incredible, and we would travel towards the same landmark for days, apparently without getting any closer, as in a bad dream. Only our tracks indicated progress. Somewhere along the coast, a cairn marked an old depot. It was laid out by an expedition around 1920. The cans were still good, but fearing they were soldered with lead, we ate only a little, remembering what lead poisoning had done to the Franklin Expedition in the mid-1800s.

Finally, our team reached our most remote depot, re-supplied, and headed for our turnaround point a few days farther west. Enormous blocks of stranded ice, which sloped steeply toward the shore, forced us onto land. I skied on the downside of the sled, trying to keep it from sliding sideways, but eventually I was overpowered and was pushed into a snow hole; the sled landed on top. Most of the load on the patrol sled was dog rations, and as we had just re-supplied, it was heavy. One runner hit my shin and lying there, my immediate fear was a broken leg. We were far away from any help, and radio contact with homebase was sketchy. Even if we got through on the radio, rescue would be almost impossible due to the distance and low temperatures. Luckily only my calf muscle was damaged. The slope and the impenetrable jumble of pack ice in Robeson Channel made further progress along the coast impossible. This was by far the farthest west in North Greenland the patrol had travelled. Our destination must have marked an important achievement for the military as well, as it hit the news in both Greenland and Denmark. We started the return trip. For the next month I limped because of my damaged muscle, and to this day, I can still see the scar where the runner hit.

Apart from the hobbling, sledding became easier as the sun got higher. Eventually we had to travel at night when the temperature was lower and the frozen snow could carry our weight. If we weren't tired, it was difficult to sleep in a white tent in full sunlight. Our return trip followed a different route, more of it inland, but apart from making our way up along the side of an active glacier and manually hauling the dogs and sled over some ice falls, progress was good.

Almost a month into our return trip we reached the Midsummer Lakes, a chain of shallow lakes connected by streams, leading east down to the coast. The lakes had been much studied for signs of ancient tent rings or fish traps, which would indicate that the humans who left Siberia for North America in the past migrated through North Greenland during their eastward progression. I was convinced that if there had been regular periods of open water along the north coast, game and people would have

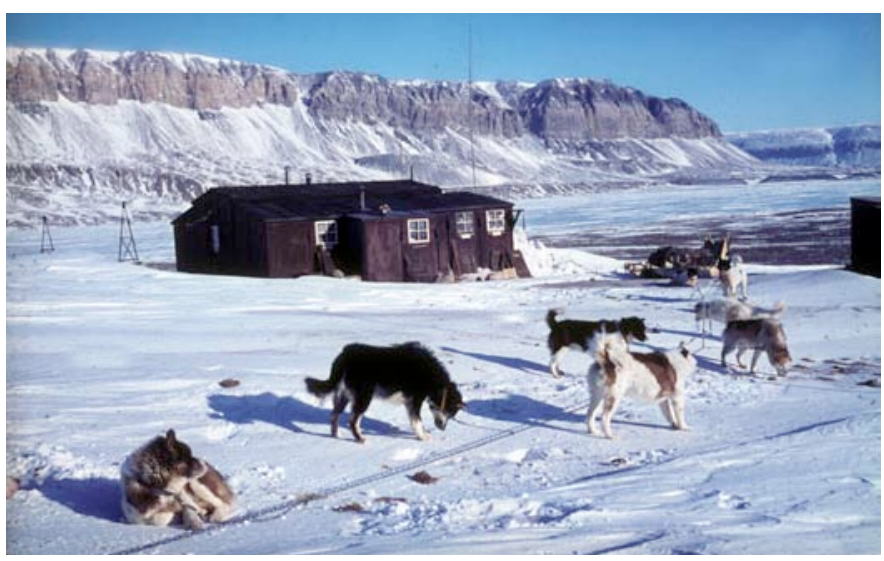

Fig. 7. Broenlundhus scientific summer station.

followed. At present there was solid ice most of the year and neither along the coast nor inland did we see signs of animal life.

Our next stop was Broenlundhus, a scientific summer field research station and the mostly northern building in the world, located by the lakes near a fjord (Fig 7). After living in a tent and eating the same atrocious rations for two months straight-a processed, dried and compressed bar of powdered beef, lard, peanut butter, ground peas, and soy, which we dissolved in a powdered soup mix-we were anxious to get inside a heated building, stand up, and eat regular food. (I had counted how many spoonfuls of the ration I could eat and had always gagged before making it to 15 .) The Patrol was once contacted by the Danish Seal Team wondering how anybody could stomach the rations the Patrol had provided. It turned out that by mistake, the team had been issued concentrated dog food.

We wanted so much to enjoy the comfort of a building, that we did more than a marathon the last day to get there, each of us jogging alongside the sled. The ice on the lakes and streams alternated between wind-polished clear ice and ice with patches of snow and exposed rocks. We had to push the sled every time the dogs were on the clear ice and unable to get a foothold. We hadn't washed for months, apart from rubbing our hands and faces in snow and brushing our teeth in a cup of water. Once a month we threw away our used underwear regardless of whether it was dirty or not. That day my long underpants fell apart, the remnants gathered above the boots inside my wind pants, which subsequently chafed my legs and made them bleed. We were in the best shape of our lives, but skinny to such an extreme that if we bumped into anything it immediately resulted in bruises because we had no fatty layer to cushion ourselves. Though I hadn't used electricity for months, I found myself naturally fumbling for the light switch as I got inside the building.

A few days after leaving Broenlundhus we returned to Station Nord, a military emergency landing strip and weather station. The U.S. Air Force was resupplying the place using transport planes, and the crew at the stations worked three shifts. We gained some notoriety by showing up for a meal, no matter the time of day, and for our stench; 
we smelled like dirty dogs, even after showering and washing our clothes. The station crew could smell that we had arrived before they saw us. For entertainment, we were invited to watch a day-long series of pornographic movies. That was even more painful than ill-fitting boots.

We went on, time was of the essence. First, we travelled south through Denmark Fjord and then over land, mostly along the inland ice, where we occasionally encountered herds of muskoxen. The creatures looked primordial and had chosen the barren north, free from wolves but with very little vegetation, over the lusher terrain farther south. The sparse dry grass and few ground-hugging bushes appeared insufficient to keep the oxen alive. In mid-winter they must have foraged almost nonstop. They were grumpy, ready for a fight, and hard to chase off. Occasionally, one would run after the sled and attack without provocation.

On our overland trip near the ice, a small, very regular, cone shaped mountain caught our attention. It turned out to have a water-filled frozen crater on top, and the formation looked like it could erupt at any time. In spite of the fact that volcanic activity dated back millions of years in Greenland, the cliffs and mountains in the area seemed to contradict that as they appeared younger. On the journey between the inland ice and Centrum Lake, a spring came out of the permafrost in a canyon some miles from a natural landing strip by the lake. The water froze when it reached the surface, and an ice dome with running water around it indicated the spot. The spring was near a seasonal creek and could therefore probably not be seen in summer. I had never before seen a spring running in winter. Only water deep underground, under pressure, and of a certain temperature, could be flowing through the permafrost. I wondered if this part of Greenland was geologically much younger than the rest of the island.

Eventually our team made it to a deserted landing strip. Under the guise of being a home base for scientific studies by an American university, "Operation Groundhog" made an area of level dirt usable after the Korean War (Fig. 8). The government feared that a future war might spread into the Arctic, and landing strips would then be needed. Quonset huts with supplies were left behind when the operation came to an end. We repaired one hut with the parts from several damaged ones, while the dogs feasted on American rations. We always boiled old cans that were dented or tarnished before opening them. If they bulged out and held pressure, we dared to eat the contents; squirting pinholes meant the food was spoiled and possibly poisonous. Some cans exploded in the boiling water, which we considered preferable to the risk of getting botulism.

When we again reached the outer coast of East Greenland, a long period of heavy fog followed, caused by the open water nearby. It was a total whiteout and we feared we might end up on an ice floe if we got too far from land. To act as dirigible landmarks for compass navigation, we had to take turns skiing as far out in front of the sled as our partner could see us in the fog. On the very day we had to find a depot on a small island, the fog lifted.

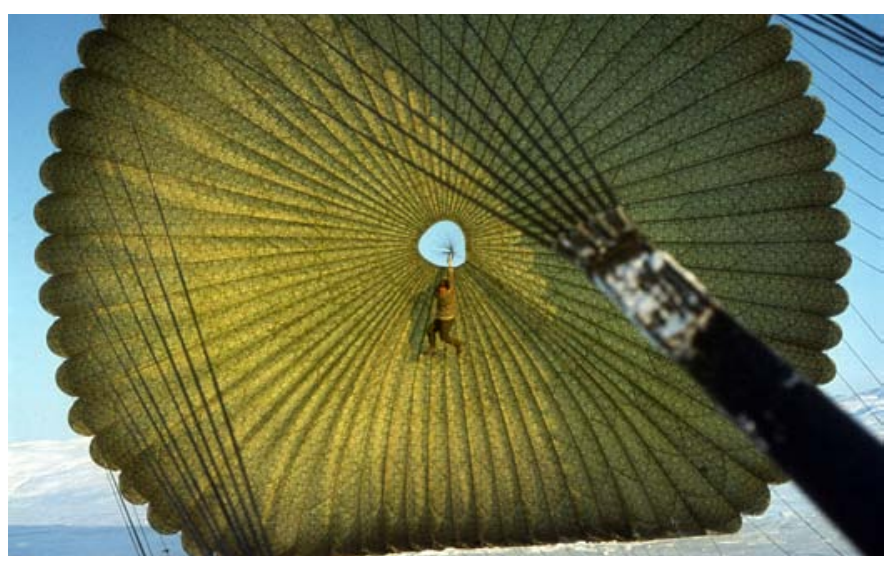

Fig. 8. Abandoned American military equipment.

That polar bears are excellent hunters is well known, but one of their methods hasn't been much described. Pregnant seals give birth out of the water in spring and will often creep through an enlarged breathing hole below a snowdrift, dig a cave, and give birth there. The bears know this and crisscross the big snowdrifts around icebergs, taking small steps while listening for changes in the sounds from below. When it finds a cave, the bear easily digs out the mother and kills it and the pup.

We avoided bears as much as possible because they are large, fast, and dangerous. If we came near one, we tried to remain calm, not to alert the dogs, and would slowly change course to evade the animal. Most bears had literally never seen anything like a sled before. Some sensed there could be danger and ran away, others had to maintain their status as top of the food chain and attacked. With their pack mentality, the dogs ran after any bear, and if we didn't have time to drop the two chain loops, which served as emergency brakes around the runners, it got ugly. Once, a large bear on the war path got entangled in the dogs' ropes, stumbled, and was struck by the sled. It bit through a runner, tore free, and lashed out at the dogs. One dog had its jaw dislocated while another was pulled straight out of its harness, all within a few seconds. I kept the metal parts of my M1 rifle from freezing together by removing all the oil and grease with boiling water before the trip. To load it, I therefore normally pulled back on the spring-activated operating rod with my heel, but an angry bear next to me was a good incentive to do so by hand and fast, and I shot it. Only later did I notice a good chunk of the skin on my hand was torn loose by the hook on the rod handle. A bear's hide with blubber on the inside freezes as it is removed and is heavy and cumbersome to transport. In order for it not to spoil, we had to bury it in snow every time we camped. It was a cumbersome process that left us wishing we never met the predator.

Some dogs eventually got tired of pulling and came up with innovative schemes to relax a bit. One would walk along in the team with all its muscles bulging, as though under the strain of heaving. It didn't realize that its sagging rope gave it away. In such cases, the worst punishment for 
the slacker was to shorten its rope, so it couldn't walk next to the team. It would almost pull the sled alone trying to catch up, and it sure got the message fast. With one female and 11 male dogs in each team, the huskies did a lot of male bonding and were devastated when they couldn't run next to their buddy (Fig. 9). At times, two dogs would be so enamored that they needed contact while pulling. First, they touched, later they leaned, and eventually tilted at a crazy angle like two cards in a card house, while still trying to pull. That wasn't conducive to the overall progress, looked pathetic, and was very difficult to put an end to.

We were sure one dog was both cross-eyed and nearsighted. It feared cracks in the ice, regardless of how narrow they were and panicked if it got near one and pushed the team in another direction. We couldn't have that and therefore took turns walking only that dog across any fissure we saw, so it wouldn't fear them. Eventually, the dog seemed to think that we wanted to cross any and every break in the ice, but as we also traveled on glaciers with wide and deep crevasses, that wasn't good either. At least the animal meant well.

The dogs didn't bond much with the men, as patrol members came and went, but they sure loved a sled with food. After a good long training day, the dogs were all let loose and sensed that fighting was inappropriate. They would gather around the patrollers, mumbling and rubbing against them while trying to gain the favor of the senior musher, and would pee on any new team member. It was also obvious that several of the strongest males in each team incessantly attempted to become the top dog and would try to control both the dog team and the mushers. They just couldn't help it.

As long as the dogs recognized the musher as dominant, we could use their behaviour to control any slackers. They were trained to recognize if we failed to praise an individual dog because it had been slacking; the larger dogs would take that as permission to attack the straggler. Eventually, whenever we stopped the sled to praise the dogs, we could skip the loafer; it would get the message and start whimpering as soon as it was bypassed, indicating that it would pick up the slack.

As the weather got milder, some of the older dogs didn't scarf down their food right away, but often rested their head on it for hours. They took pleasure in watching their neighbours strain at their chains, whimpering and scraping in the snow for the longest time, attempting to get at the food. One dog had noticed that yanking and shaking the main chain really irritated the rest of the team, but it never learned to beware of low temperatures, and one time its mouth froze to the chain. Skin from its lips and tongue stuck to it as the dog let go. It clearly hurt, but he soon forgot and did it again.

We learned some training techniques from the Inuit. When they select a suitable candidate for top dog, they let it fight the other males in the team under conditions so unfair that it always wins. They also feed it first and better than the rest of the dogs and it pulls on the longest rope. Eventually,

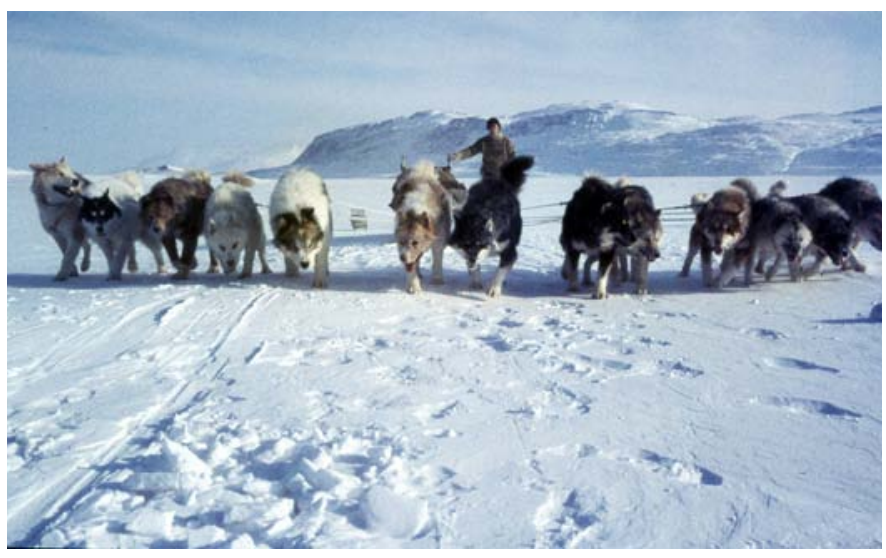

Fig. 9. Dogs walking close to their buddies.

the team comes to accept that dog as the boss and it then keeps the rest of the animals subdued and prevents fights. The Inuit don't pet their dogs, neither do they beat them; when a dog is too old to keep up, they hang it.

Puppies born in the dark without any human contact for the first few days would always turn into shy dogs. They pulled like mad and feared human contact.

The female dog was always cute and cuddly with us, and when the whole dog team was in a big fight, the male dogs wouldn't bite her, but she wouldn't hesitate to bite them. Whenever she was in heat, it was hard keeping her on the straight and narrow.

We always looked forward to spending a night or two at one of the abandoned hunting stations. Some had an oven and were stocked with flour and temperamental dried yeast making it possible to bake bread. In one, we heated up the coal-fired oven, made enough dough for two breads, and waited for it to rise. After several hours, not much had happened, so we mixed in a lot more dried yeast. The breads took shape and went into the oven. A rather short time later the oven door flew open and the breads caught fire, which we extinguished with snow. What we had baked was now one big loaf, which totally filled the oven and had to be loosened with a snow shovel. After the burned crust had been removed, we agreed it was one of the fluffiest and best tasting breads we ever had.

The iron clad rule in the patrol was that you didn't leave any shelter before it was made ready to receive the next visitor, who might arrive cold and exhausted. The fire in the stove was extinguished, the ashes removed and kindling left in a can with fuel. A half-opened matchbox was placed next to it, so a man could grab a match with his teeth, in case his hands were frozen.

In one hunting station, these preparations made it possible to arrange a good scare for the next visitors. Getting ready to leave the hut took time, and the building would get so cold that an old wind-up gramophone that had been left behind wouldn't turn. For a prank, we cranked it up, put on a record, and hid it in a closet. When the next team arrived, it took a long time before the heat reached the gramophone. By that time the two men would 
have eaten and would be dozing, enjoying the heat. The unthawing gramophone would eventually start turning at a very slow speed, producing an eerie low mumbling sound accompanied by a loud screeching from the needle. It would scare anybody. When that team left, it would be their turn to install the gramophone for the next visitors.

By the middle of June, when we were finally nearing home base, the coastal ice was melting and the streams running, making progress difficult. If the thaw started before the ice broke up, the runoff could not drain through it, but would instead collect on top, and we would end up walking in ankle deep, ice cold slush-we'd have the beginnings of trench foot and no place to camp. The dogs would get desperate and climb on top of the sled whenever possible. On land we had to watch out for collapsing snow dams and flash floods as we crossed stream beds. East Greenland could easily have claimed to have 10 months of winter and two months of bad sledding.
I liked sledding and patrolling, but not the extreme cold. What really drew me was the opportunity to get into almost untravelled territory and just see what there was to see. It was an exhilarating feeling and quite addictive.

When we reached home base, we had been patrolling for more than five months, had covered about $3600 \mathrm{~km}$, lost one dog to a bear, had not broken any limbs, had had extremely stable weather, and considered the trip a success. I knew this was the best job I ever had or would have, and that I was good at it.

Torben Eriksen is a former radio operator who spent his youth patrolling North and East Greenland for the Danish government. Danish-born, he is now a retired contractor and lives with his family in northern California.

familyeriksen@gmail.com 